\section{Exploration of modern microbialites with calcium and magnesium stable isotopes, mineralogy, and elemental composition: Storr's Lake, San Salvador Island, The Bahamas}

\author{
BRITTAN WOGSLAND ${ }^{1}$, ZIJIAN LI ${ }^{2}$, DAVID J \\ WRONKIEWICZ ${ }^{3}$, MATTHEW S FANTLE ${ }^{4}$, MAJIE FAN ${ }^{5}$ \\ AND ELIZABETH M. GRIFFITH ${ }^{6}$ \\ ${ }^{1}$ University of Tennessee at Knoxville, Earth and Planetary \\ Sciences Department \\ ${ }^{2}$ Georgia Institute of Technology \\ ${ }^{3}$ Missouri University of Science \& Technology \\ ${ }^{4}$ Pennsylvania State University \\ ${ }^{5}$ University of Texas at Arlington \\ ${ }^{6}$ The Ohio State University \\ Presenting Author: bwogsla1@vols.utk.edu
}

Modern microbialites grow within the hypersaline, turbid, high magnesium ( $\mathrm{Mg}$ ) and calcium $(\mathrm{Ca})$ content (and $\mathrm{Mg} / \mathrm{Ca} \sim 4.5$ ), shallow $(<2 \mathrm{~m})$ Storr's Lake on San Salvador Island, The Bahamas. The average alkalinity was $130 \pm 23 \mathrm{mg} / \mathrm{L}$ as $\mathrm{CaCO}_{3}$ $( \pm 2 \mathrm{SD} ; \mathrm{n}=23)$ at the time of sample collection in January 2016. In Storr's Lake, living planktonic, motile microorganisms and suspended algal and bacterial debris create high turbidity that rapidly attenuates sunlight penetration in the water column. Carbon (C) isotopes of microbialite carbonate samples suggest both photosynthesis and extracellular polymeric substance (EPS) degradation control organo-mineralization. High-Mg calcite (HMC) of $\sim 14 \mathrm{~mol} \% \mathrm{Mg}$ is dominant in the top irregular surfaces of the mounds, but aragonite is enriched in the interior. Aragonite occurs in all microbialites sampled from around the lake except one of the shallowest mounds, at $40 \mathrm{~cm}$ water depth (depth at the time of sampling). Two mounds collected from the deep part of the lake $(>110 \mathrm{~cm})$ were measured for $\mathrm{Ca}$ and $\mathrm{Mg}$ stable isotopes - notably one was buried in soft organic-rich calcareous ooze, but the other was not. Both $\delta^{44 / 40} \mathrm{Ca}$ and $\delta^{26} \mathrm{Mg}$, ranging from 0.38 to $0.94 \%$ (rel. $915 \mathrm{a}$ ) and -2.33 to $-3.04 \%$ (rel. DSM3) respectively, are controlled by mineralogy (and $\mathrm{Sr}$ and $\mathrm{Mg}$ content). For both isotopic systems, lake water was homogeneous and similar to seawater.

Isotopic fractionation during incorporation of $\mathrm{Ca}$ and $\mathrm{Mg}$ into microbialite carbonate was compared with other carbonate systems to explore the potential influence of microbial processes on their isotopic composition. In both isotopic systems, HMC falls within the range of biologically mediated samples. Less clarity exists for aragonite-rich samples, which fall within the range for biotic and abiotic samples in both isotopic systems.

Carbonate $\delta^{44 / 40} \mathrm{Ca}$ and $\delta^{26} \mathrm{Mg}$ values have the potential to record original mineralogy in the rock record and may hold the key to illuminating early diagenetic changes within microbial mats and other carbonate systems. Larger data sets in a wider variety of settings including lithified microbialites are needed to make strong conclusions about the formation and early diagenesis of the microbialites within Storr's Lake, and their 